\title{
Experiences with a white clover-based dairy system in the Netherlands
}

\author{
R.L.M. SCHILS \\ Research Station for Cattle, Sheep and Horse Husbandry, Runderweg 6, 8219 PK Lelystad, The Netherlands
}

\begin{abstract}
Recent developments, such as the introduction of milk quota and concern about nitrogen $(\mathrm{N})$ losses in dairy farms, have started a downward trend in $\mathrm{N}$ inputs. Consequently there is renewed interest in white clover in the Netherlands. From May 1990 to April 1993 two 60-cow dairy systems based on either grass-N swards or grass-clover swards were compared. Because of the expected yield difference of $15-20 \%$, the grass- $\mathrm{N}$ and grass-clover farm had pasture areas of 34 and 41 ha, respectively. The grass-N and grass-clover swards were fertilised with 275 and $69 \mathrm{~kg} \mathrm{~N} / \mathrm{ha} /$ year, respectively. The main objective was to compare both systems on their technical, environmental and financial performance. With similar amounts of concentrates, the annual milk production per cow was slightly higher in the grass-clover system, the difference occurring during the grazing season. Gross margin per cow was also higher in the grass-clover system, but the lower stocking rate gave a lower gross margin per ha. Nitrogen surplus and energy use were approximately $15 \%$ lower with grass-clover than with grass-N. The technical and environmental results demonstrate that white clover-based swards are a viable option for the future, but at present dairy farming is still very intensive and for most dairy farmers it is financially unattractive to switch from grass- $\mathrm{N}$ to grass-clover.
\end{abstract}

Keywords: dairy system, energy use, gross margin, milk production, nitrogen balance, Trifolium repens

\section{Introduction}

The introduction of milk quota and an increasing concern about nitrogen $(\mathrm{N})$ losses in dairy production systems (Aarts et al. 1992) have led to a reduction in $\mathrm{N}$ input and renewed interest in white clover (Trifolium repens) in the Netherlands. Owing to government regulations (MHPPE \& MANF 1995), aimed at reducing $\mathrm{N}$ losses, a further reduction in stocking rate may soon be expected, increasing the scope for white clover.

To evaluate the consequences of using white clover on Dutch dairy farms, a research programme was started in 1989. This paper focuses on the systems research, which consisted of a comparison between a grass-only, fertiliser N-based dairy farm, and a grass-white cloverbased dairy farm. The main objective was to compare both systems on their technical, environmental and financial performance.

\section{Methods}

\section{Site}

The research was conducted at the Waiboerhoeve experimental station at Lelystad $\left(52^{\circ} \mathrm{N}, 5^{\circ} \mathrm{E}\right)$ from May 1990 until April 1993. The soil was a young calcareous marine clay (illitic mesic hydric fluvaquent), reclaimed from the sea 40 years ago. The organic matter content in the topsoil $(0-5 \mathrm{~cm})$ ranged from $4 \%$ in newly sown swards to $15 \%$ in old (25 years) swards. Available phosphorus (P) and potassium (K) were 16 and $34 \mathrm{mg} /$ $100 \mathrm{~g}$ dry soil, respectively. For grassland on clay soils these values are regarded as 'sufficient' for P and 'very high' for K (MANF 1989).

Over the two years, before the start of the comparison, grass-white clover swards were established. Nearly $65 \%$ of the area was ploughed and reseeded with mixtures of perennial ryegrass (Lolium perenne, $20 \mathrm{~kg}$ / ha) and white clover $(5 \mathrm{~kg} / \mathrm{ha})$. On the remaining area white clover was introduced by sod seeding $(5 \mathrm{~kg} / \mathrm{ha})$. The main sown clover varieties were Retor, Alice and Milkanova on 65, 15 and 5\% of the area, respectively. In order to have similar sward ages in both systems, an equivalent area was renewed on the grass- $\mathrm{N}$ farm. Each autumn the botanical composition was determined by means of a visual estimation of ground cover.

Compared with the 30 -year mean, springs and summers (April-August) have been drier and warmer during the experiment, while the autumns (SeptemberNovember) have been wetter than normal (Figure 1).

Figure 1 Mean monthly water surplus (rainfall-evaporation) and temperature during the 3-year experiment compared with the 30-year mean.

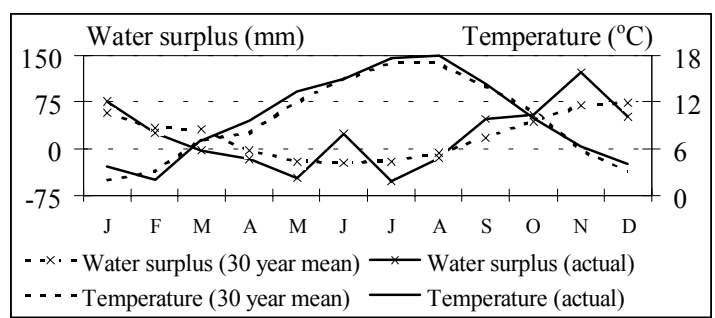




\section{Systems layout}

The experiment was designed so that the only difference between the systems was their pasture type and area. Both herds were run by one farm manager and housed under one roof, but in completely independent units with separated silage storage, feeding passages and slurry storage. A basic principle for both systems was that they had equal milk quota of 450 tonnes and they had to be self supporting in silage. As the dry matter yield per ha in the grass-clover system was expected to be 15 to $20 \%$ lower than in the grass-N system, 34 and 41 ha were allocated to grass-N and grass-clover, respectively (Table 1). The herds consisted of Holstein-Friesian cows, calving from October to April.

Table 1 System layout for the grass-N and grass-white clover farm.

\begin{tabular}{lcc}
\hline & Grass-N & Grass-clover \\
\hline Area (ha) & 34 & 41 \\
Dairy cows & 59 & 59 \\
Youngstock & 40 & 40 \\
Stocking rate $(\mathrm{LU} / \mathrm{ha})^{*}$ & 2.2 & 1.9 \\
Milk $\left(10^{3} \mathrm{~kg} / \mathrm{ha}\right)$ & 13.2 & 11.0 \\
\hline
\end{tabular}

* LU=Livestock Unit: 0-1 year $=0.3 ; 1-2$ year $=0.6 ;$ cow $=1.0$

On both farms the grassland area was divided into paddocks of $1.25 \mathrm{ha}$, so that there were 27 paddocks of grass-N and 33 of grass-clover. A rotational grazing system was used for both herds and a paddock was usually grazed for 1 or 2 days by cows followed by another 1 or 2 days grazing by young stock and dry cows. The first priority was the availability of grass for grazing, while surplus grass was cut for silage. During the grazing season, which lasts from the first week of April until the last week of October, cows were supplemented with 1 to $6 \mathrm{~kg}$ of concentrates per day, depending on milk yield. From November to March cows were housed and fed silage (ad libitum) and concentrates ( 1 to $12 \mathrm{~kg} / \mathrm{cow} /$ day). The aim was to maintain the concentrate levels per cow per year at a similar level in both systems.

Each spring slurry was applied to all paddocks with a shallow disk injector at a rate of $20 \mathrm{~m}^{3} /$ ha. Average nutrient contents per $\mathrm{m}^{3}$ slurry were $2.1 \mathrm{~kg} \mathrm{NH}_{4}-\mathrm{N}$, $0.7 \mathrm{~kg}$ P and $6.5 \mathrm{~kg} \mathrm{~K}$. Some paddocks received a second application during the summer. On grass-clover swards fertiliser-N was only applied in spring. Grass-only swards received fertiliser- $\mathrm{N}$ in 5 to 7 dressings, depending on the number of grazings and silage cuts. All paddocks received additional fertiliser-P depending on available $\mathrm{P}$ in the soil and the number of silage cuts. Additional fertiliser-K was not necessary because of the very high $\mathrm{K}$ contents in the soil.
Nitrogen fixation by white clover was estimated as follows. First a total DM yield per ha was calculated from the silage yield and the number of grazing days. These yields and clover contents in the sward were combined to calculate an annual clover yield. With the assumption that each tonne of clover DM is equivalent to a $\mathrm{N}$ fixation of $54 \mathrm{~kg} / \mathrm{ha}$ (Van der Meer \& Baan Hofman 1989) the total fixation was estimated. The energy use of both systems was calculated with the ENERGY module of a farm budgeting program (Hageman \& Mandersloot 1995).

\section{Results and discussion}

Unless stated otherwise, the results were meaned over 3 years (May 1990-April 1993).

\section{Sward composition}

Although the mean white clover content was satisfactory, the differences between paddocks were very large (Figure 2). Firstly, sod seeding led to a variable clover establishment. Secondly, paddocks sown with the variety Alice maintained a higher proportion of white clover than paddocks sown with Retor or Milkanova. The poorer persistence of Retor compared with Alice could have been due to a greater susceptibility to slug damage (Baars et al. 1996). Thirdly, some variation could be explained by differences in pasture management, for instance frequent topping of rejected herbage stimulated clover, whereas grazing under wet conditions was often followed by a decrease in clover content. During the experiment the ground cover of other species, like rough stalked meadowgrass (Poa trivialis) and annual meadowgrass (Poa annua), increased at the cost of perennial ryegrass.

Figure 2 Botanical composition of grass-clover swards in the autumn; mean, minimum and maximum values of 33 paddocks.

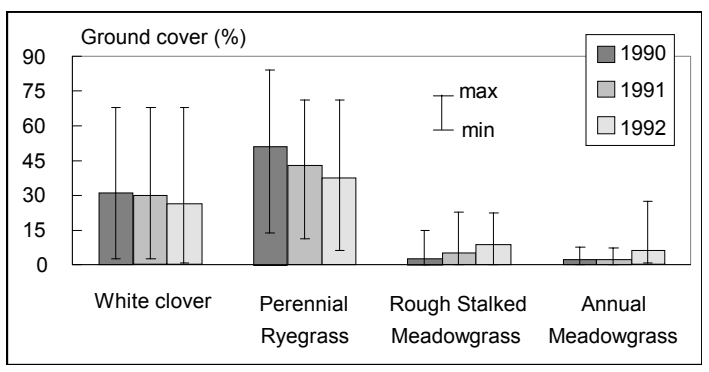

In the grass-N swards perennial ryegrass was the main species with 52 to $90 \%$ cover, followed by rough stalked meadowgrass (0-24\%) and annual meadowgrass 
$(0-13 \%)$. Volunteer white clover was hardly present $(0-1 \%)$.

\section{Pasture utilisation}

Average annual slurry application was $32 \mathrm{~m}^{3} /$ ha on grass$\mathrm{N}$ swards and $25 \mathrm{~m}^{3} /$ ha on grass-clover swards. So on grass-clover the main proportion of applied $\mathrm{N}$ was derived from slurry (Table 2).

Table 2 Pasture utilisation.

\begin{tabular}{|c|c|c|}
\hline & $\begin{array}{c}\text { grass } \\
\mathrm{N}\end{array}$ & $\begin{array}{l}\text { grass } \\
\text { clover }\end{array}$ \\
\hline Area (ha) & 34 & 41 \\
\hline Nitrogen application (kg/ha) & 275 & 69 \\
\hline Phosphorus application (kg/ha) & 51 & 49 \\
\hline Potassium application (kg/ha) & 208 & 161 \\
\hline Total grazing days ( $\left.10^{3} \mathrm{LU}\right)$ & 14.7 & 15.4 \\
\hline Grazings (per paddock) & 4.4 & 4.9 \\
\hline Total silage yield $\left(10^{3} \mathrm{~kg}\right)$ & 194 & 226 \\
\hline Silage cuts (per paddock) & 1.9 & 2.4 \\
\hline Aftermath grazings (per paddock) & 0.4 & 0.5 \\
\hline Topping rejected herbage (per paddock) & 1.2 & 0.7 \\
\hline
\end{tabular}

The total number of grazing days and the number of grazings per paddock were slightly lower on the grass$\mathrm{N}$ farm. This was caused by a drought of 1 month in the summer of 1990 and 2 months in 1991. In these periods cows on the grass-N farm were allowed to graze only during daytime and were supplemented with silage at night. White clover growth was affected less severely, so there was no need for supplementation. The surplus of herbage on the grass-clover farm was reflected strongly in the number of silage cuts and the total silage yield. The higher cutting frequency on the grass-clover swards enabled more grazing on aftermath and reduced the need for topping herbage. The yield differences and the need for silage supplementation on the grass- $\mathrm{N}$ farm resulted in an annual silage shortage of $12 \mathrm{tDM}$ in the grass system and an annual silage surplus of $29 \mathrm{t} D \mathrm{DM}$ in the grass-clover system.

Silage cuts were made at yields of 2-3 t DM/ha. Silage quality (Table 3) was similar in both systems. The crude protein content of grass-clover silage made in August and September tended to be higher than those of grass-only silage. Values of net energy for lactation were similar.

Table 3 Average silage quality (standard deviation in brackets).

\begin{tabular}{lcc}
\hline & $\begin{array}{c}\text { grass } \\
\mathrm{N}\end{array}$ & $\begin{array}{c}\text { grass } \\
\text { clover }\end{array}$ \\
\hline Number of samples & 29 & 38 \\
Dry Matter (g/kg product) & $434(93)$ & $434(108)$ \\
VEM (per kg DM)* & $850(61)$ & $859(58)$ \\
Crude Protein (g/kg DM) & $168(21)$ & $179(28)$ \\
\hline${ }^{*}$ Net energy for lactation (Van Es 1977) & \\
\hline
\end{tabular}

\section{Milk production}

As mentioned earlier, the concentrate levels per cow per year were deliberately maintained at similar levels. However, within a year variations occurred owing to differences in calving patterns. Although the herds had a similar calving pattern at the start, unequal shifts in calving patterns were introduced by randomly variable insemination results.

Table 4 Daily intake rate and milk production per cow.

\begin{tabular}{lcccc}
\hline & \multicolumn{2}{c}{--- Apr-Oct --- } & \multicolumn{2}{c}{--- Nov-Mar ---- } \\
& grass & grass & grass & grass \\
clover & $\mathrm{N}$ & clover \\
\hline Concentrates (kg)* & 3.7 & 3.5 & 6.1 & 5.8 \\
Silage (kg DM) & 0.7 & - & 13.5 & 14.4 \\
Milk (kg) & 24.7 & 25.2 & 26.0 & 25.9 \\
Fat (\%) & 4.27 & 4.36 & 4.75 & 4.62 \\
Protein (\%) & 3.47 & 3.47 & 3.47 & 3.45 \\
BSK $^{* *}$ & 38 & 39 & 40 & 40
\end{tabular}

* Per kg: 940 VEM and $160 \mathrm{CP}$

** Milk production, corrected for differences in lactation stage

During the grazing season the cows were supplemented with approximately $3.5 \mathrm{~kg}$ of concentrates per day (Table 4). During the droughts cows on grass-N were fed silage at a rate of $5 \mathrm{~kg} \mathrm{DM} / \mathrm{cow} /$ day, or $0.7 \mathrm{~kg} \mathrm{DM} /$ cow/day meaned over the whole grazing season. Milk production and fat content were slightly higher in the grass-clover system. These differences occurred from July onwards, but it is not certain that they can be attributed to white clover directly. The higher proportion spent on aftermath might also have contributed to the increased production. During winter, production levels were nearly similar, despite a higher silage intake of grass-clover.

On an annual basis fat- and protein-corrected milk production were 8095 and $8294 \mathrm{~kg} / \mathrm{cow}$ for grass-N and grass-clover respectively, with a concentrate use of 1828 and $1847 \mathrm{~kg} / \mathrm{cow} /$ year, respectively.

\section{Nitrogen balance}

The higher intensity of the grass-N system gave a higher $\mathrm{N}$ surplus per ha. The different stocking rates of the farms are directly reflected in the $\mathrm{N}$ input through concentrates and the $\mathrm{N}$ output through milk and cattle. On the grass- $\mathrm{N}$ farm there was a small $\mathrm{N}$ input through silage that had to be bought to compensate for the shortages. The silage surpluses of the grass-clover farm were sold and they are on the balance as a negative input. In this region of the Netherlands the atmospheric deposition of $\mathrm{NH}_{3}-\mathrm{N}$ is $35 \mathrm{~kg} \mathrm{~N} /$ ha/year.

The $\mathrm{N}$ surplus of the grass-clover farm complies with the target of $220 \mathrm{~kg} \mathrm{~N} / \mathrm{ha} /$ year, set by the government for the year 2008 (MHPPE \& MANF 1995). 
Table 5 Nitrogen balance ( $\mathrm{kg} \mathrm{N} /$ ha/year).

\begin{tabular}{lcc}
\hline & grass-N & grass-clover \\
\hline - Total input & $\mathbf{3 3 3}$ & $\mathbf{2 7 9}$ \\
Concentrates & 76 & 65 \\
Fertiliser & 208 & 16 \\
Fixation & 4 & 180 \\
Silage & 9 & -18 \\
Deposition & 35 & 35 \\
Litter & 1 & 1 \\
• Total output & $\mathbf{8 0}$ & $\mathbf{6 9}$ \\
Milk 70 & 61 & 8 \\
Cattle & 10 & $\mathbf{2 1 2}$ \\
- Surplus & $\mathbf{2 5 3}$ & \\
\hline
\end{tabular}

\section{Energy use}

The direct energy use was similar, but the indirect energy use of the clover based system was $15 \%$ lower than that of the fertiliser N-based system, the main difference being the fertiliser use (Table 6). The higher number of silage cuts, which are all done by contractors, on the grass-clover farm gave a higher energy use in 'services'. The difference in silage shortage/surplus is reflected in 'other'.

The energy use per $100 \mathrm{~kg}$ of milk was 440 and $374 \mathrm{MJ}$ for grass-N and grass-clover, respectively. A study by Hageman \& Mandersloot (1995) showed that the energy use in the Netherlands ranged from 373 to $741 \mathrm{MJ} / 100 \mathrm{~kg}$ milk.

Table 6 Energy use (GJ/year).

\begin{tabular}{lrr}
\hline & grass-N & grass-clover \\
\hline • Direct energy & $\mathbf{3 4 4}$ & $\mathbf{3 4 3}$ \\
Diesel & 124 & 122 \\
Electricity & 220 & 221 \\
• Indirect energy & $\mathbf{1 6 1 9}$ & $\mathbf{1 3 5 4}$ \\
Concentrates & 672 & 675 \\
Fertiliser & 286 & 37 \\
Services & 230 & 293 \\
Buildings \& Machinery & 331 & 333 \\
Other & 100 & 16 \\
- Total & 1963 & $\mathbf{1 6 9 7}$ \\
\hline
\end{tabular}

\section{Gross margin}

Total revenues of the grass-clover farm were higher due to higher milk sales and the sale of the silage surplus (Table 7). The slightly lower revenues from cattle sales was caused by one cow, dying of bloat in 1992. In 1989, during the establishment phase, two cows also died of bloat. So in 1990 and 1991, in order to prevent bloat, the grass-clover cows were fed $1 \mathrm{~kg} / \mathrm{cow} /$ day of a concentrate to which Centralene (polyoxypropylene and polyoxyethylene) was added. Although it worked satisfactorily, it increased the concentrate costs.
However, from 1992 onwards the health authorities prohibited the further use of Centralene, classifying it as a medicine, which cannot be added to concentrates. Fertiliser costs were lower in the clover system. Although whole farm gross margin and gross margin per cow were higher for the clover system, the lower stocking rate gave a lower gross margin per ha.

Table 7 Gross margin $\left(10^{3} \mathrm{NZ} \$ \text { year }\right)^{*}$.

\begin{tabular}{lcc}
\hline & grass-N & grass-clover \\
\hline • Total revenues & 338 & 351 \\
Milk 300 & 306 & 37 \\
Cattle & 38 & 8 \\
Silage & 0 & 66 \\
• Direct costs & 71 & 37 \\
Concentrates & 34 & 3 \\
Fertiliser & 8 & 0 \\
Silage & 3 & 26 \\
Other & 26 & \\
• Gross margin & & 285 \\
Whole farm & 267 & 7.0 \\
Per ha & 7.8 & 4.8 \\
Per cow & 4.6 & \\
* 1 NZ\$ = 1.16 Dutch guilder & & \\
** health, interest, Al & & \\
\hline
\end{tabular}

\section{Conclusions}

The results have demonstrated that, for both technical and environmental reasons, white clover-based swards are a viable option for the future. Calculations with a farm budgeting program, based on these results, have shown that a switch from grass-N to grass-clover is financially attractive for farms that use up to $250 \mathrm{~kg} \mathrm{~N} /$ ha on their grassland (Schils et al. 1995). However, present dairy farming is still very intensive, and in 1993 for instance only $5 \%$ of the grassland area on sandy soils was fertilised with less than $250 \mathrm{~kg} \mathrm{~N} / \mathrm{ha}$.

One of the major drawbacks of white clover for farmers is its irregular content in the sward. Some variation in clover content is unavoidable but the extremes encountered on some paddocks were unacceptable. Particularly the paddocks with the highest clover contents caused problems with bloat and nitrate leaching (Schils 1994).

Although the comparison with grass-N was not continued in 1994, the existing grass-clover system is still being further developed. Most remaining questions are directly or indirectly related to the irregularity in white clover content. A major change that took place in order to tackle these problems was the introduction of 4 ha of forage maize. From July onwards, when clover contents are steadily rising, 2 to $3 \mathrm{~kg}$ DM of maize silage have been supplemented to the cows. This reduces 
the $\mathrm{N}$ surplus in the diet and it reduces the bloat risk. Moreover, management strategies are being developed to try to regulate the clover content within certain ranges. This involves close monitoring of botanical composition and frequencies of absence, followed by decisions to cut or graze with a certain frequency or even to reintroduce new grass or clover seeds into a sward.

\section{REFERENCES}

Aarts, H.F.M.; Bieuwinga, E.E.; van Keulen, H. 1992. Dairy farming systems based on efficient nutrient management. Netherlands journal of agricultural science 40: 285-299.

Baars, T.; van Dongen, M.; Brands, L. 1996. Early crop growth, yield and clover development in cut and grazed grass/clover mixtures under organic conditions. pp. 122-125. In: Frame, J. (ed.). Recent research and development on white clover in Europe. REUR Technical Series 42.

Hageman, I.W.; Mandersloot, F. 1995. Energy use and methods for reduction. pp. 44-47. In: Luten, W.; Snoek, H.; Schukking, S.; Verboon, M. (eds). Applied research for sustainable dairy farming. Proceedings of the symposium.
Ministery of Agriculture, Nature management and Fisheries. 1989. Fertiliser recommendations for grassland and fodder crops. (In Dutch)

Ministery of Housing, Physical Planning and Environment; Ministery of Agriculture, Nature management and Fisheries. 1995. Integrated report on slurry and ammonia policy. (In Dutch)

Schils, R.L.M. 1994. Nitrate losses from grazed grass and grass/clover pastures on clay soil. Meststoffen 1994: 78-84.

Schils, R.L.M.; Verboon, M.C.; Boxem, T.; Antuma, S.J.F. 1995. Reduction of $\mathrm{N}$ fertilisation and introduction of white clover. Publication no. 106. Research Station for Cattle, Sheep and Horse Husbandry. (In Dutch)

van der Meer, H.G.; Baan Hofman, T. 1989. Contribution of legumes to yield and nitrogen economy of leys on a biodynamic farm. pp. 25-36. In: Plancquaert, P.; Haggar, R. (eds). Legumes in farming systems. EEC Brussels.

van Es, A.J.H. 1977. Feed evaluation for ruminants. I. The systems in use from May 1977 onwards in the Netherlands. Livestock production science 5: 331345 . 
